\title{
PENGARUH VARIASI PRODUK, HARGA, DAN CUSTOMER EXPERIENCE TERHADAP KEPUTUSAN PEMBELIAN ULANG ROTI BREADTALK YOGYAKARTA
}

\author{
Penny Rahmawati, MSi \\ Email penny_rahmawaty@uny.ac.id
}

Jurusan Manajemen Fakultas Ekonomi, Universitas Negeri Yogyakarta

\begin{abstract}
ABSTRAK
Perubahan dan perkembangan masyarakat mengakibatkan masyarakat lebih menginginkan sesuatu yang praktis dalam segala hal, termasuk makanan yang akan dikonsumsi. Masyarakat kadang jenuh dengan konsumsi makanan sehari-hari dan mengiginkan sesuatu yang berbeda.Hal ini dilihat dari sisi bisnis oleh para produsen produk makanan, termasuk untuk produk roti. Beberapa produsen yang menciptakan produk roti banyak bermunculan dalam pasar, roti yang mempunyai ciri khas rasa dan bentuk masingmasing seperti yang dihasilkan oleh produsen roti yang terkenal di Yogyakarta.Khususnya Breadtalk menampilkan inovasi yang diharapkan mampu menarik konsumen/pasar yang dituju supaya bersedia membeli produk yang ditawarkannya. Penelitian ini bertujuan untuk mengetahui pengaruh keragaman produk(X1), harga(X2), dan customer experience $(X 3)$ terhadap pembelian ulang produk $(Y)$ roti Breadtalk. Analisis data menggunakan metode kuantitatif dengan SPSS. Jenis penelitian menggunakan alat analisis regresi linier berganda. Populasi dalam penelitian ini adalah seluruh mahasiswa Universitas Negeri Yogyakarta. Sampel diambil dari mahasiswa fakultas ekonomi sebanyak 100 responden.
\end{abstract}

Hasil penelitian menunjukkan bahwa customer experience berpengruh positif terhadap pembelian ulang roti Breadtalk. Manajemen Breadtalk sebaiknya mempertahankan dan meningkatkan keragaman produk, harga dan customer experience sehingga pembelian ulang konsumen lebih meningkat lagi.

Kata Kunci : keragaman produk, harga, customer experience, keputusan pembelian ulang.

\section{Latar Belakang}

Berkembangnya teknologi yang sangat pesat, perusahaan dituntut untuk bersaing secara cermat dan tanggap dalam melihat peluang, ancaman, tantangan, hambatan, dan gangguan baik itu perusahaan dalam posisi pemimpin pasar, maupun pengikutnya, maka dari itu persiapan dari segala jenis bentuk, terutama dalam segi kualitas produk, harus diperhatikan dengan seksama. Sehingga persaingan yang semakin ketat tersebut, setiap usaha perlu meningkatkan kekuatan yang ada dalam perusahaannya dengan cara memunculkan perbedaan atau keunikan yang dimiliki perusahaan dibandingkan dengan pesaing untuk dapat menarik minat konsumen.

Perubahan masyarakat dan perkembangan teknologi di era globalisasi ini mengakibatkan masyarakat lebih menginginkan sesuatu yang praktis dalam segala hal, termasuk makanan yang akan dikonsumsi. Masyarakat kadang jenuh 
dengan konsumsi makanan sehari-hari dan mengiginkan sesuatu yang berbeda.Hal ini dilihat dari sisi bisnis oleh para produsen produk makanan, termasuk untuk produk roti.

Pembelian ulang (repeat purchase) menurut Peter \& Olsen (2002) adalah : Kegiatan pembelian yang dilakukan lebih dari satu kali atau beberapa kali. Kepuasan yang diperoleh seorang konsumen, dapat mendorong ia melakukan pembelian ulang (repeat purchase), menjadi loyal terhadap produk tersebut ataupun loyal terhadap toko tempat dia membeli barang tersebut sehingga konsumen dapat menceritakan hal hal yang baik kepada orang lain.

Menampilkan inovasi yang diharapkan mampu menarik konsumen/pasar yang dituju supaya bersedia membeli produk yang ditawarkannya. Beberapa keunggulan yang ditawarkan antara lain : harga, rasa, image, kualitas, pelayanan, variasi produk, dan lokasi, dll. Untuk produk roti Breadtalk sendiri saat ini berlokasi di Ambarukmo Plaza dan Malioboro Mall.Sedangkan segmen yang dilayani adalah semua kalangan yang menetap di Yogyakarta. Variasi produk yang bermacam-macam jenisnya merupakan sebuah hasil dari inovasi suatu perusahaan, khususnya produk roti Breadtalk. Produk ( product ) menurut Kotler \& Armstrong, (2001: 346) adalah segala sesuatu yang dapat ditawarkan kepasar untuk mendapatkan perhatian, dibeli, digunakan, atau dikonsumsi yang dapat memuaskan keinginan atau kebutuhan. Selain melihat dari segi produk, antrian yang begitu panjang di gerai roti Breadtalk juga karena harga yang ditawarkan untuk masing-masing produknya untuk menarik minat calon pembeli. Harga merupakan salah satu faktor penentu dalam pemilihan merek yang berkaitan dengan keputusan membeli konsumen.Menurut Swastha (2005) mengatakan bahwa harga adalah jumlah uang (ditambah beberapa barang kalau mungkin) yang dibutuhkan untuk mendapatkan sejumlah kombinasi dari barang beserta pelayanannya.

Pengalaman masa lampau pelanggan (customer experience) meliputi hal-hal yang telah dipelajari atau diketahui pelanggan dari yang pernah diterimanya dimasa lalu.Menurut Meyer and Schwager (dalam Pramudita dan Japarianto, 2012) customer experience (pengalaman pelanggan) adalah tanggapan pelanggan secara internal dan subjektif sebagai akibat dari interaksi secara langsung maupun tidak langsung dengan perusahaan. Dimanacustomer experiencemeliputi sense, feeling, thinking, action, relation experience.

Produk yang bervariasi, dan harga produk yang relative terjangkau sampai harga yang mahal dari gerai toko lainnya, serta pengalaman pembelian konsumen, begitu banyaknya pembeli yang merasa 
ingin membeli lagi dengan rela mengantri, dimana gerai BreadTalk itu sendiri tidak begitu besar dan luas. Dengan demikian, peneliti ingin mengetahui pengaruh variasi produk, harga,dan menciptakan lebih dari 160 varian produk yang menawarkan gayahidup baru dalam menyantap roti. Pada tahun 2004, BreadTalk (Indonesia) berhasil meraih best seller product versi majalah marketing untuk product signaturenya, yaitu C's flosss danfire Flosss yang per harinya terjual sekitar 20.000 buah (http://shiochi.blogspot.com/2013/02/a nalisis-swot-breadtalk.html).

Pada tahun 2002 BreadTalk menerima SPBA Paling Menjanjikan Brand Award dan dipilih oleh konsumen sebagai Suzzana 3,3\% Buana Bakery 2,7\% Roti Boy 2,6\% Kartika Sari 1,9\%. (http:// www.topbrand-award.com/topbrand-survey/surveyresult/top_brand_index_2013_fase_2).

Tujuan penelitian ini adalah:

(1) untuk mengetahui pengaruh variasi produk terhadap pembelian ulang produk roti Breadtalk,

(2) untuk mengetahui pengaruh harga terhadap pembelian ulang produk roti Breadtalk,

(3) untuk mengetahui pengaruh customer experience terhadap pembelian ulang produk roti Breadtalk. customer experience terhadap keputusan pembelian ulang roti merek Breadtalk.

Dalam soal cita rasa, BreadTalk terus berinovasi. Sampai saat ini BreadTalk berhasil

Merek Paling Populer, George Quek memenangkan Entrepreneur of the Year Award ( ASME dan Rotary Club ), BreadTalk peringkat No.1 di Enterprise 50 Startup Award (Accenture dan The Business Times ), BreadTalk cepat mengembang hingga 20 outlet di Singapura.

(http://www.breadtalk.com/historymilestones.html). TOKO ROTI / BAKERY Merek TBI TOP Holland Bakery 31,7\% TOP Bread Talk 21,7\% TOP Majestyk 7,4\% Swiss Bakery 3,7\%

\section{Landasan Teori}

Keputusan Pembelian Ulang

Menurut Schiffman \&Kanuk (2008:506) perilaku pembelian ulang itu berhubungan erat dengan konsepdaribrand loyalty yang diusahakanoleh kebanyakan perusahaan karenamenyumbang kepada stabilitas yanglebih besar di pasar. Pembelian ulangbiasanya menandakan bahwa produkmemenuhi persetujuan konsumendan bahwa ia bersedia memakainyalagi dan dalam jumlah yang sangatbesar. Sedangkan menurut Kotler dan Keller (2009:226) terdapat 6keputusan yang dilakukan olehpembeli, yaitu: pilihan produk, pilihanmerek, pilihan dealer, jumlahpembelian, saat yang 
tepatmelakukan pembelian, dan metode pembayaran.

\section{Produk dan Keragaman Produk}

Produk menurut Stanton yang dikutip oleh Buchari Alma (2007:139), merupakan seperangkat atribut baik berwujud maupun tidak berwujud, termasuk di dalamnya masalah warna, harga, nama baik pabrik, nama baik toko yang menjual (pengecer), dan pelayanan pabrik serta pelayanan pengecer yang diterima oleh pembeli guna memuaskan keinginannya. Pengembangan produk yang bervariatif dengan jaminan mutu kualitasnya, akan membuat harapan terhadap minat konsumen untuk mengkonsumsinya dalam usaha memenuhi kebutuhan hidup dari para konsumen. Ketertarikan konsumen terhadap produk yang bervariatif akan sangat mempengaruhi volume penjualan.Variasi produk adalah pengembangan dari suatu produk sehingga menghasilkan bermacam-macam pilihan.

H1 :variasi produk mempunyai pengaruh positif terhadap keputusan pembelian pada produk roti Breadtalk Yogyakarta

\section{Harga}

Harga menurut Kotler dan Amstrong (2001) adalah sejumlah uang yangditukarkan untuk sebuah produk atau jasa.Lebih jauh lagi, harga adalah sejumlahnilai yang konsumen tukarkan untuk sejumlah manfaat dengan memiliki ataumenggunakan suatu barang atau jasa.Harga merupakan hal yang diperhatikankonsumen saat melakukan pembelian.Sebagian konsumen bahkan mengidentifikasikan harga dengan nilai.Harga adalah sejumlah uang yang dikeluarkan konsumen untuk mendapatkan produk dan pelayanannya. Memiliki indikator sebagai berikut (Kotler, 1997; Tjiptono, 2006):

a. Terjangkau atau tidaknya harga

b. Kesesuaian antara harga dengan kualitas/rasa

c. Persaingan harga

d. Kesesuaian antara harga dengan kuantitas

H2 :Harga mempunyai pengaruh negatif terhadap keputusan pembelian pada produk roti Breadtalk Yogyakarta

Customer Experience (Pengalaman Konsumen)

Penggunaan customer experience diharapkan dapat menaikkan penjualan restoran tersebut. Menurut Meyer and Schwager (dalam Pramudita dan Japarianto, 2012) Customer experience (pengalaman pelanggan) adalah tanggapan pelanggan secara internal dan subjektif sebagai akibat dari interaksi secara langsung maupun tidak langsung dengan perusahaan. Dimana customer experience meliputi sense, feeling, thinking, 
action, relation experience.Menurut Schimtt (dalam Kustini, 2007) sense experience adalah usaha penciptaan suatu pengalaman yang berkaitan dengan panca indra melalui penglihatan, suara, sentuhan, rasa, dan bau. Feeling experience dapat ditampilkan melalui ide, kesenangan, dan reputasi akan pelayanan pelanggan. Pengalaman dapat menjadi suatu ide pemasaran yang mempengaruhi secara efektif dengan cara memahami secara mendalam terhadap emosi dan suasana hati yang mampu membangkitkan kebahagiaan atau bahkan kesedihan. Thinking experience adalah meliputi creative dan cognitive, maksud dari creative dan cognitive adalah bahwa untuk pemikiran pemasaran menuntut kecerdasan dengan tujuan menciptakan pengalaman kognitif dan pemecahan masalah dengan melibatkan pelanggan secara kreatif. Action experience menurut Schmitt (dikutip Kustini, 2007) adalah didesain untuk menciptakan pengalaman pelanggan yang berhubungan dengan tubuh secara fisik, pada perilaku dan gaya hidup jangka panjang serta pengalamanpengalaman yang terjadi sebagai hasil dari interaksi dengan orang lain. Menurut Schimtt (dalam Kustini, 2007) relation experience secara umum menunjukkan adanya hubungan dengan orang lain, kelompok sosial lain (seperti pekerjaan, gaya hidup) atau identitas sosial yang lebih luas.

H3 :customer experience mempunyai pengaruh positif terhadap keputusan pembelian pada produk roti Breadtalk Yogyakarta.

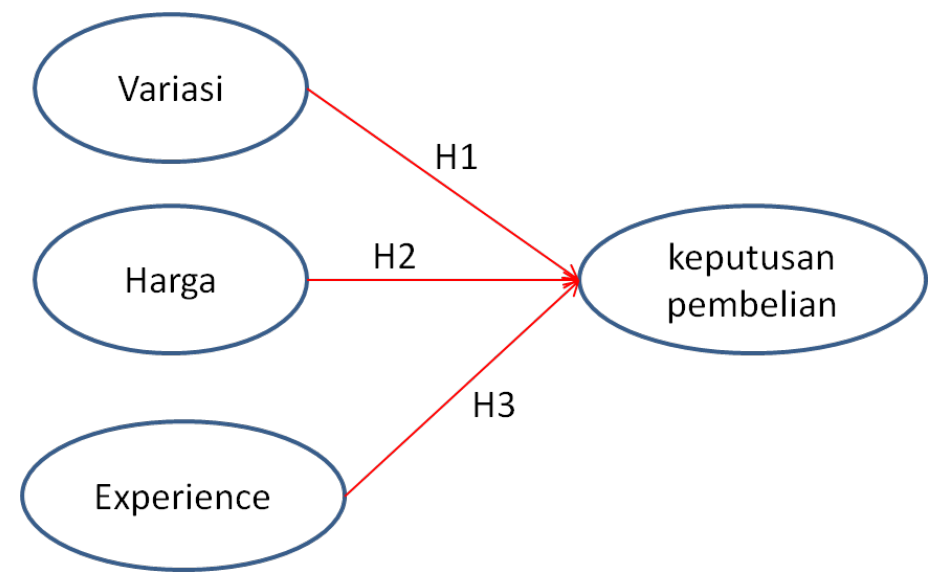

\section{Metodologi}

\section{Jenis dan Waktu Penelitian}

Dalam penelitian ini, penulis menggunakan pendekatan kuantitatif, sedangkan menurut eksplanasinya penelitian ini merupakan penelitian yang bersifat korelasional, yaitu suatu metode penelitian yang bertujuan untuk mengetahui pengaruh antara dua variabel atau lebih. Menggunakan regresi berganda 
untuk mendapatkan hasil perngaruh antar variabel yang diteliti.

\section{Populasi}

Menurut Sugiyono (2008), populasi adalah wilayah generalisasi yangterdiri atas: obyek/subyek yang mempunyai kualitas dan karakteristik tertentuyang ditetapkan oleh peneliti untuk dipelajari dan kemudian ditarikkesimpulannya.Populasi adalah keseluruhan objek yang diteliti.Populasi yang digunakan dalam penelitian ini adalah seluruh mahasiswa fakultas ekonomi, Universitas Negeri Yogyakarta yang telah melakukan pembelian ulang pada semua jenis produk Breadtalk.

\section{Sampel}

Untuk menentukan sampel yang diambil menggunakan non probability sampling, yaitu teknik pengambilan sampel dimana tidak semua anggota populasi dalam posisi yang sama-sama memiliki peluang untuk dipilih menjadi sampel.Metode pengambilan sampelnya menggunakan accidental sampling, yaitu metode pengambilan sampel yang dilakukan dengan menggunakan siapa saja yang ditemui secara kebetulan sebagai sampel.Responden yang menjadi sampel adalah responden dari mahasiswa fakultas ekonomi Universitas Negeri Yogyakarta yang pernah melakukan pembelian ulang roti Breadtalk wilayah Yogyakarta.

\section{Definisi Operasional dan}

\section{Pengukuran Variabel}

Variabel dependen dalam penelitian ini adalah Minat Beli Ulang Konsumen (Y).Perilaku pembelian ulang itu berhubungan erat dengan konsep dari brand loyalty yang diusahakan oleh kebanyakan perusahaan karena menyumbang kepada stabilitas yang lebih besar di pasar. Pembelian ulang biasanya menandakan bahwa produk memenuhi persetujuan konsumen dan bahwa ia bersedia memakainya lagi dan dalam jumlah yang sangat besar. Variabel independen adalah variabel yang mempengaruhi variable dependen, baik yang pengaruhnya positif maupun yang pengaruhnya negative (Ferdinand, 2006). Variabel independen dalam penelitian ini adalah:

a. Variasi produk $\left(\mathrm{X}_{1}\right)$

Produk merupakan seperangkat atribut baik berwujud maupun tidak berwujud, termasuk di dalamnya masalah warna, harga, nama baik pabrik, nama baik toko yang menjual (pengecer), dan pelayanan pabrik serta pelayanan pengecer yang diterima oleh pembeli guna memuaskan keinginannya. Variasi produk adalah pengembangan produk sehingga menghasilkan bermacam-macam pilihan.

b. Harga $\left(X_{2}\right)$

Harga adalah sejumlah uang yang dikeluarkan konsumen untuk mendapatkan produk dan pelayanannya. Memiliki indikator sebagai berikut :

a. Terjangkau atau tidaknya harga 
b. Kesesuaian antara harga dengan kualitas/rasa

c. Persaingan harga

d. Kesesuaian antara harga dengan kuantitas

c. Pengalaman konsumen $\left(X_{3}\right)$
Customer experience (pengalaman pelanggan) adalah tanggapan pelanggan secara internal dan subjektif sebagai akibat dari interaksi secara langsung maupun tidak langsung dengan perusahaan. Dimana customer experience meliputi sense, feeling, thinking, action, relation experience.

Alat Ukur

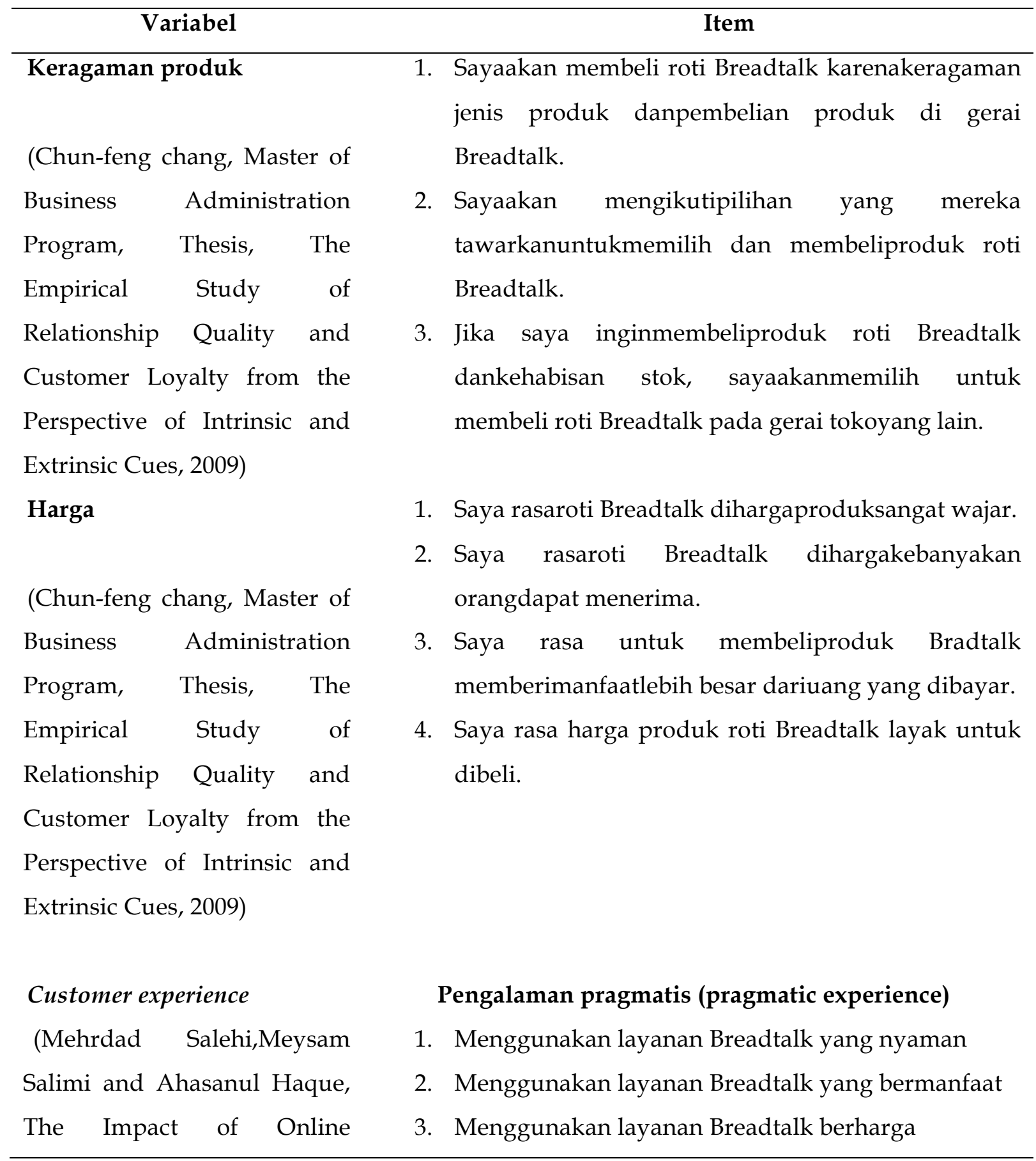




\begin{tabular}{llll}
\hline Customer Experience $(\mathrm{OCE})$ & 4. & Menggunakan layanan Breadtalk yang informatif \\
on Service Quality in & 5. & Menggunakan layanan Breadtalk berguna \\
Malaysia, 2013) & 6. & Menggunakan layanan Breadtalk yang \\
& & menyenangkan & \\
7. & Layanan langsung Breadtalk memotivasi saya untuk \\
& terus membeli \\
& Pengalaman kegunan (usability experience)
\end{tabular}

1. Sangat mudah untuk menggunakan layanan Breadtalk

2. Karena kemudahan tsb, tidak membingungkan untuk menggunakan layanan Breadtalk

3. Hal ini tidak melelahkan untuk menggunakan layanan Breadtalk

4. Hal ini mudah untuk menggunakan layanan Breadtalk

5. Hal ini tidak stres untuk menggunakan layanan Breadtalk

\section{Pengalaman hedonis ( Hedonis Experience)}

1. Saya senang dengan menggunakan layanan Breadtalk

2. Saya senang dengan layanan Breadtalk

3. Saya senang dengan layanan yang diberikan oleh lingkungan Breadtalk

4. Hiburan yang disediakan oleh layanan Breadtalk dapat menyesuaikan suasana hati saya

5. Saya tetarik oleh layanan Breadtalk yang saya gunakan

\section{Pengalaman sosialisasi (Keramahan Experience)}

1. Layanan Breadtalk ramah

2. Layanan Breadtalk sopan

3. Layanan Breadtalk adalah untuk perorangan 


\begin{tabular}{|c|c|}
\hline Keputusan pembelian ulang & $\begin{array}{l}\text { 1. Saya berniat untuk membeli produk Breadtalk. } \\
\text { 2. Saya berniat membeli kembali setiap kali ada produk }\end{array}$ \\
\hline $\begin{array}{l}\text { (Chun-Chen Huang, The } \\
\text { Relationship Among Brand }\end{array}$ & $\begin{array}{l}\text { Breadtalk, dan ketika ada produk yang baru saya } \\
\text { akan membelinya. }\end{array}$ \\
\hline $\begin{array}{l}\text { Equity, Customer Satisfaction, } \\
\text { And Brand Resonance To }\end{array}$ & $\begin{array}{l}\text { 3. Saya berniat untuk membeli produk Breadtalk } \\
\text { dalam waktu dekat. }\end{array}$ \\
\hline Repurchase Intention Of & 4. Saya akan mendukung orang lain (keluarga, teman, \\
\hline $\begin{array}{l}\text { Cultural And Creative } \\
\text { Industries In Taiwan, 2014) }\end{array}$ & $\begin{array}{l}\text { dll) agar membeli produk Breadtalk. } \\
\text { 5. Saya akan bergabung dengan kelompok yang suka } \\
\text { membeli produk Breadtalk }\end{array}$ \\
\hline
\end{tabular}

\section{Hasil dan Pembahasan}

Dari hasil analisis faktor didapatkan bahwa faktor loading lebih dari 0.3 hanya variabel customer experience (var 10, 13, $15,17,18,19,20,26,27)$ dan pembelian ulang (var 31,33,35), sedangkan untuk keragaman produk hanya dari 3 pertanyaan yang memenuhi hanya 1 (var 5) dan harga tidak memenuhi).Hasil regresi berganda menunjukkan bahwa keragaman produk, harga, dan customer experience, tidak memberikan pengaruh pada keputusan pembelian ulang roti bradtalk bagi mahasiswa. Sedangkan uang saku memberikan pengaruh pada keputusan pembelian ulang roti bradtalk bagi mereka.

Tabel Regresi

\begin{tabular}{|c|c|c|c|c|c|c|c|c|c|}
\hline & \multicolumn{3}{|c|}{ Tahap 1} & \multicolumn{2}{|c|}{ Tahap 2} & \multicolumn{2}{|c|}{ Tahap 3} & \multicolumn{2}{|c|}{ Tahap 4} \\
\hline & $\beta$ & & $\mathrm{p}$ & $\beta$ & $p$ & $\beta$ & $\mathrm{p}$ & $\beta$ & $\mathrm{p}$ \\
\hline gender & & -.098 & .317 & -.101 & .299 & -.104 & .293 & -.105 & .291 \\
\hline umur & & .060 & .540 & .077 & .433 & .079 & .427 & .079 & .427 \\
\hline uang saku & & -.320 & .001 & -.335 & .001 & -.336 & .001 & -.336 & .001 \\
\hline produk & & & & -.128 & .191 & -.130 & .189 & -.133 & .186 \\
\hline Harga & & & & & & -.021 & .829 & -.019 & .847 \\
\hline pengalaman & & & & & & & & -.020 & .841 \\
\hline
\end{tabular}

\section{REFERENSI}

Chang, Chun-feng.2009., The Empirical Study of Relationship Quality and Customer Loyalty from the Perspective of Intrinsic and Extrinsic Cues. Master of
Business Administration Program. Thesis.

Salehi, Mehrdad, Meysam Salimi and Ahasanul Haque.2013.The Impact of Online Customer Experience (OCE) on Service Quality in Malaysia. 
Kotler, Philip. 2001. Manajemen Pemasaran di Indonesia : Analisis, Perencanaan, Implementasi dan Pengendalian. Salemba Empat. Jakarta.

Kusumawati, Ika dan Sutopo. 2013. DIPONEGORO JOURNAL OF MANAGEMENT Volume 2, Nomor 2, Tahun 2013, Halaman 1-9.Analisis Pengaruh Customer Experience Terhadap Minat Beli Ulang (Studi Kasus Pada Konsumen Restoran The House Of Raminten Yogyakarta). Jurusan Manajemen Fakultas Ekonomika dan Bisnis Universitas Diponegoro Liwe, Farli. 2013. Jurnal EMBA 2107 Vol.1 No.4 Desember 2013, Hal. 2107-2116. Kesadaran Merek, Keragaman Produk,
Dan Kualitas Produk Pengaruhnya Terhadap Pengambilan Keputusan Konsumen Membeli Di Kentucky Fried Chicken Manado. Fakultas Ekonomi dan Bisnis, Jurusan Manajemen Universitas Sam Ratulangi

Manadohttp://www.idosi.org/wasj/wasj 21\%2811\%2913/11.pdf

cust.experience

http:/ / ethesys.lib.fcu.edu.tw/ETDsearch/view_etd?URN=etd-0729109$\underline{192756}$

keragaman produk, hargahttp://www.topbrandaward.com/top-brandsurvey/surveyresult/top_brand_index_2013_fase_2 